\title{
Döl Tutmayan İneklerde İmmunolojik İnfertilitenin Araştırılması
}

\author{
B. Kemal GÜMÜŞAY ${ }^{1}$, İshak GÖKÇEK ${ }^{2 *}$, ilker YAVAŞ ${ }^{3}$ \\ ${ }^{1}$ Gıda Tarım ve Hayvancılık Bakanlığı Hassa İlçe Tarım Müdürlüğü, Hatay, Türkiye. \\ ${ }^{2}$ Mustafa Kemal Üniversitesi Veteriner Fakültesi Fizyoloji Anabilim Dalı, Hatay, Türkiye. \\ ${ }^{3}$ Mustafa Kemal Üniversitesi Veteriner Fakültesi Dölerme ve Suni Tohumlama Anabilim Dalı, Hatay, Türkiye.
}

Geliş Tarihi: 14.03.2018

Kabul Tarihi: 08.06.2018

\begin{abstract}
Özet: Hayvancılık işletmelerinin geleceği açısından ineklerden yavru elde edilmesi çok önemli yer teşkil eder. İneklerde infertilite nedenleri çok çeşitlidir. Bunlar arasında herediter, işlevsel (anöstrus, suböstrus, kistler), enfeksiyöz hastalıklar, bakım ve besleme bozuklukları sayılabilir. Günümüzde yukarıda sayılan bu nedenlerin bulunmadığı durumlarda bile yapılan çok sayıda tohumlamaya rağmen bazı ineklerde gebe kalamama olgularının görülmesi dikkat çekicidir. Bu çalışmada infertil ineklerde immunglobulin seviyelerine bakılarak immünolojik infertilitenin tespiti ve immünolojik infertilitenin görülme sıklığının araştırılması amaçlanmıştır. Çalışmada, özel işletmelerde bulunan ve en az 3 kere tohumlandığı halde gebe kalmayan, rektal ve ultrason ile yapılan muayenede fertiliteye engel herhangi bir bozukluğu bulunmayan, daha önce en az bir kere sorunsuz doğum yapmış inekler kullanılmıştır. Tohumlama sonrası elde edilen kan serumu örneklerinde ELISA testi ile antisperm antikorları tespit edilmiştir. Sonuç olarak, normal saha koşullarında test edilen herhangi bir rahatsızlığı bulunmayan, en az 3 kere tohumlanmış ama gebe kalmamış ineklerin kan serumlarında ELISA testi ile \% 14,33 oranında antisperm antikorları (ASA) tespit edilmiştir.
\end{abstract}

Anahtar Kelimeler: Infertilite, Immunolojik infertilite, Salgısal immunglobülin A, Suni tohumlama.

\section{Investigation of Immunological Infertility in Repeat Breeder Cows}

Abstract: In terms of the future of livestock businesses, obtaining calf from cows is crucial. There are many factors that prevent fertility. These factors include hereditary and functional problems (an- oestrus, sub-oestrus, cysts), infectious diseases, and miscarriage. It is noteworthy that some cows do not become pregnant despite the numerous inseminations even in the absence of an appearent reason. In this study it was aimed to investigate the incidence of immunological infertility by determining immunglobulin levels in repeat breeder cows. In the study 50 cows which calved at least once and were not pregnant despite at least 3 subsequent inseminations although they did not have any disorders preventing fertility as assessed by rectal and ultrasonographic examinations, were used. Antisperm antibodies (ASA) were detected by ELISA test in blood serum samples obtained after insemination. As a result, ASA were detected in $14.33 \%$ of the cows that were at least 3 times inseminated but not conceived at any time in normal field conditions.

Keywords: Infertility, Immunological infertility, Secretory immuneglobulin A, Artificial insemination.

\section{Giriş}

Üreme fizyolojisi alanındaki yapılan çalışmalara ve gelişmelere rağmen hayvanlarda infertilite olgularının \%30-40'ında belirlenebilir bir neden (idiopatik infertilite) bulunamamıştır. Birçok araştırmacı, spermaya karşı oluşan antikorların (ASA) idiopatik infertilitenin oluşum sebeplerinden biri hatta en önemlisi olabileceğini ifade etmektedir (Risvanlı ve ark., 2005). Vücudun tüm mukozal yüzeylerinde olduğu gibi dişi genital kanal mukozal yüzeyinde de lizozim, laktoferrin, laktoperoksidaz gibi enzimler ile mukus varlığı önemli savunma faktörleridir. Ayrıca tüm mukozal yüzeylerde en çok bulunan antikor salgısal immunglobulin A (slgA) 'dır. Immunglobulin A kandan mukozal yüzeylere geçerken salgısal bir parça eklenir ve salgısal immunglobulin A (slgA) halini alır (Rodney ve David, 2017). Böylece slgA mukozal yüzeylerdeki enzimlerin yıkımlayıcı etkilerinden korunmuş olur. slgA'nın en önemli fonksiyonu yabancı maddelerin epitel hücrelerine bağlanmasını engellemektir. Sperma, dişi genital kanalıyla ilk olarak vaginada karşılaşır. Vaginaya bırakılan spermaya karşı dişi immun sistem tarafından immunosupresif etki oluşturulur. Bu durum spermaya karşı oluşabilecek olan antikorların sperme yapışabilmesini engeller. Seminal plazmada da bir çok immunosupresif faktörün varlığı iddia edilmiştir (Price ve ark., 1984). Dişi reprodüktif sisteminde enfeksiyon gibi lokal immun cevabı stimule eden yardımc faktörler seminal plazmanın immunosupresif etkisini değiştirir veya spermlerle çapraz reaksiyon veren antikorların oluşumuna yol açarlar (Wolff ve Schill, 1985). Ürogenital kanalda spermaya karşı lokal olarak oluşan bu izoantikorlar, spermatozoonların fonksiyonları üzerinde farklı etkilere sahiptirler. Bunların arasında spermatozoon motilitesinde azalma, migrasyonun engellenmesi ve aglütinasyon reaksiyonu gibi faktörler sayılmaktadır (Price ve ark., 
1984; Doğan ve Gökçen, 2001). Dişi reprodüktif kanalda, östrus döneminde, serviks uterinin açılmasına paralel olarak immunglobulin $G$ ve immunglobulin A sınıfı antikorların çoğaldığı tespit edilmiştir (Minbay, 1994).

Bu çalışmada geçmişinde en az bir kez doğum yapmış fakat en az 3 tohumlamadan bu yana döl tutmayan ineklerin infertilite nedeninin immunolojik yönden araştırılması amaçlanmıştır. Böylece idiyopatik (nedeni bilinmeyen) infertilite içinde bulunan immunolojik infertilite oranın belirlenmesi amaçlanmıştır.

\section{Materyal ve Metot}

Mustafa Kemal Üniversitesi Hayvan Deneyleri Yerel Etik Kurulu (HADYEK) 26.02.2015 tarihli toplantı 2015-2-9/132 sayılı kararı alındıktan sonra çalışmamız başlamıştır. Çalışmamızda, özel işletmelerde bulunan daha önce en az bir kez doğum yapmış düzenli aralıklara östrüs belirtileri gösterebilen, genital kanalda enfeksiyonlarmetritis, pyometra, klinik endometris yönünden muayene edilen ve genital bir enfeksiyon belirlenmeyen fakat en az 3 suni tohumlamadan bu yana döl tutmayan genel sağlık taraması yapılmış 50 baş inek kullanıldı. Ineklerin kızgınlık takipleri yapıldı. Kızgınlık döneminde partikül veya kötü koku bulunmayan şeffaf berrak renkli çara gözlemlendi. Kızgınlık belirtileri gösteren ineklerin rektal palpasyon ve ultrasonla folliküler aktivitesine bakılarak östrüsün 12-18'inci saatleri arasında derin ipsi lateral rektovaginal yöntemle suni tohumlaması yapıldı. Suni tohumlamadan 4 saat sonra juguler venden antikoagülanlı tüplere kan alındı. Alınan numuneler soğuk zincirde laboratuvara getirildi. Kan örnekleri $(10 \mathrm{ml})$ standart prosedürle $3000 \mathrm{rpm}$ devirde 20 dakika santrifüj edilerek kan serumları elde edildi. Elde edilen kan serumları laboratuvar analizleri yapılıncaya kadar -20 santigrat (C) derecede muhafaza edildi. Tohumlamalarda Progeny testi yapılmış boğalardan elde edilen dondurulmuş sperma payetleri kullanıldı. Bireysel farklılıkları önlemek amacıyla aynı boğaya ait spermaları içeren payetler kullanıldı ve kullanım öncesi en az 3 payet çözdürülerek tam spermatolojik muayene yapıldı. Serum örneklerinde Enzyme-linked Immune Sorbent Assay (ELISA) testi ile (Kim ve ark., 1999) antisperm antikorları tespit edildi. Analizde Yehua Biological Technology Co., Ltd. firmasından temin edilen Bovine secretory immunoglobulin A ( $\operatorname{sg} A)$ ELISA kiti kullanıldı. Analiz öncesi örnekler, standartlar ve reagentler hazırlandı. Hazırlanan numunelere ve standartlara, biyotin ve ELISA çözeltileriyle etiketlenmiş ikinci antikorlar eklendi. $37{ }^{\circ} \mathrm{C}$ 'de 60 dakika boyunca reaksiyona girmesi sağlandı. Plaka 5 kez yıkandı. Ardından reagent A ve
B eklendi ve renk gelişimi için ve $37^{\circ} \mathrm{C}^{\prime}$ de 10 dakika inkübe edildi. Daha sonra durdurma solüsyonu eklenerek reaksiyon sonlandırıldı. Plaka 10 dakika içinde Eliza okuyucuda 450 nanometrede ölçüldü.

\section{Bulgular}

ELISA testi sonuçlarına göre negatif serum absorbans değeri 0.380 OD (absorbans değeri) olarak saptandı. Bu değer ve altındaki absorbans değeri gösteren kan serumu slgA düzeyleri negatif kabul edildi. 0.380 ile 0.820 OD aralığındaki numuneler ise ASA pozitif veya negatif olarak kabul edilmedi. 0.820 OD'dan büyük absorbans değerleri ise olumlu bir tepkinin göstergesi olarak kabul edildi. Bu değerden daha yüksek absorbans değeri gösteren kan serumu slgA düzeyleri için antisperm antikoru (ASA) pozitif olduğu belirlendi. ASA pozitif olduğu tespit edilen hayvanların oranı ise 50 baş inek arasında \%14.33 olarak kaydedildi.

Tablo 1. İnek serumlarında slgA düzeyleri.

\begin{tabular}{lc}
\hline \multicolumn{2}{c}{ Eliza Testi Sonuçları } \\
\hline Numune İndeksi & Sonuç \\
$<0.380$ OD & Negatif ASA (-) \\
$\geq 0.820$ OD & Pozitif ASA (+) \\
Ortalama Değer & Standart Sapma \\
$0.572(0.095-1.220)$ OD & $\pm 0,314$ \\
\hline
\end{tabular}

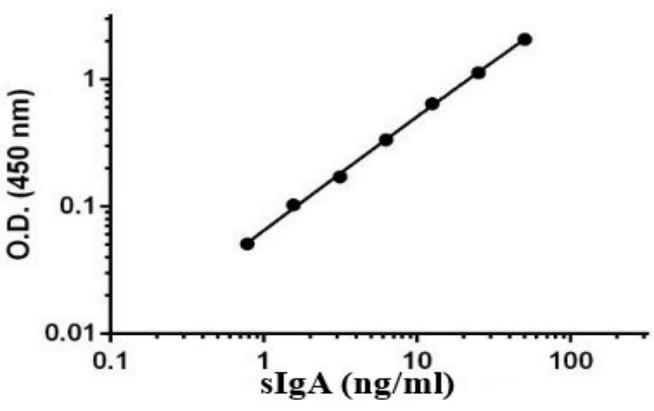

Şekil 1. Serum İmmunglobulin A (sIgA) ELISA sonucu.

\section{Tartışma ve Sonuç}

Birçok araştırmacı, spermaya karşı oluşan antikorların (ASA) idiopatik infertilitenin oluşum sebeplerinden biri hatta en önemlisi olabileceğini ifade etmektedir (Risvanlı ve ark., 2005). Bununla birlikte, ideal laboratuvar ve klinik koşullarda dahi infertilitenin yalnızca \%60-70'inin nedeni saptanabilir düzeydedir; saha koşullarında bu oran $\% 50$ 'den daha aşağıya düşer. Bu nedenle idiyopatik infertilitenin nedenlerinin belirlenmesi önemli bir konudur. Son zamanlarda, idiyopatik infertilitenin nedenlerinden biri olarak immünolojik faktörlerin önemli bir rol oynadığı öne sürülmüştür (Alexander 
ve Anderson, 1989; Risvanli ve Kaygusuzoğlu, 2004). Çalışmamızda elde ettiğimiz sonuçlar klinik olarak gebe kalmasına engel bir neden bulunmamasına rağmen 3 veya daha fazla tohumlamada gebe kalmamış ineklerdeki infertilite olgusuna immunolojik faktörlerin etkisi olabileceği yönündedir. Spermatozoonların testiste üretimi sırasında geniş bir yelpazedeki antijenik yapılar bileşime eklenmektedir. Bir sperm hücresi üzerinde birçok protein bulunur. Bu proteinlerden hangisinin dişi genital kanalında bir bağışıklık tepkisine neden olduğu iyi bilinmemektedir. Kadın vücudunda ASA oluşumunu kolaylaştıracak spermatozoa üzerinde FA1 ve laktik dehidrogenaz C4 gibi birçok antijenik yapı bulunduğu ortaya konmuştur (Bradley ve ark., 1997; Naz, 1999). Reprodüktif organların ve kanın içindeki ASA varlığı genellikle insanlarda, laboratuvar hayvanlarında ve çiftlik hayvanlarında infertiliteye yol açmaktadır (Waziri ve Fayemi, 2000; Srivastava ve ark., 2017). Çalışmamızda elde ettiğimiz slgA düzeyleri bu bilgileri destekler niteliktedir. ASA'dan dolayı infertil olan dişilerin oranını tahmin etmek zordur. Bazı dişilerde ASA oluşumuna neden olabilecek birçok faktör vardır. Bu nedenler arasında dişinin immünolojik durumu, sperma konsantrasyonu, çiftleşmenin sayısı olduğu gibi ayrıca dişilerde farklı stres koşulları veya kortikosteroid kullanımı sayılabilir. Buna ek olarak, spermatozonların kanla temas etmesi sonrası hayvan vücudunda ASA'lar geliştiği bilinmektedir; bu nedenle yangısal durumlar, örneğin; metritis, vajinitis veya çiftleşme sırasında meydana gelen travma ve kanamalar bu antikorların gelişiminde önemli rol oynar (Panchal ve ark., 1990). Çiftlik hayvanlarının yaşam koşulları ve saha koşullarının zorluğu düşünülünce yukarıda bahsedilen ASA oluşumuna neden olabilecek faktörlerin sabit tutulması ve ASA oranın tespit edilmesi zor olabilmektedir. Bu nedenle çiftlik hayvanlarında ASA oranının tam olarak tespit edilebilmesi için stres koşulları, kortikosteroid kullanımı ve spermatozoonların dişide kanla teması gibi durumların sabit tutulduğu daha ileri çalışmaların çiftlik hayvanlarında da yapılması gerektiği düşünülmektedir. ASA varlığında ejakülat hacminin, sperm sayısının, sperma motilitesinin ve spermatozoonların bağlanma kapasitelerinin olumsuz etkilendiği bildirilmiştir (Zral ve ark., 2002). Çalışmamızda ticari olarak satılan sperma payetlerinin kullanılması ile ejekülat hacmi ve spermatozoon sayısının bir örnek olması sağlanmış ve bu faktörlerin sonuçlara etki etmediği düşünülmektedir. Suni tohumlama öncesi kullanılacak payetlerde spermatolojik muayene yapılmasıyla sperma motilitesinin de sonuçları etkilemediği düşünülmektedir. Ayrıca aynı boğaya ait sperma payetleri kullanılmasıyla bireysel farklılığın sonuçlara etki etmediği düşünülmektedir. $\mathrm{Bu}$ bilgiler doğrultusunda özellikle doğal aşımla çiftleştirilen dişilerde ejekülat hacminin fazlalığı ve genital kanal yaralanmaları dikkate alındığında ASA oluşumunun artabileceği düşünülmektedir. Ayrıca ineklerde suni tohumlama esnasında suni tohumlama kateterinin ilerletilmesi esnasında manipülatif hatalar sonucu şekillenen genital kanal yaralanmalarında da ASA oluşumunun görülebileceği düşünülmektedir. İneklerde ASA varlığının tekrarlanan tohumlama nedeniyle spermlere karşı oluşturulan aynı antikorlar veya spesifik antikorlarla farklı antijenlerin çapraz reaktivitesinden kaynaklanabileceğini bildirmişlerdir (Ahuja ve ark., 2016). Bu bilgi doğrultusunda ineklerde aynı boğaya ait spermlerin kullanılması immunolojik infertilitenin nedeni olabilmektedir. Bu faktörün fertiliteye etkisini azaltmak amacıyla immunolojik infertil şüpheli hayvanlarda farklı boğa spermaları ile tohumlama yapılmasının faydalı olacağı düşünülmektedir.

Sonuç olarak; normal saha koşullarında test edilen herhangi bir rahatsızlığı bulunmayan, en az 3 kere tohumlanmış ama gebe kalmamış ineklerin serumlarında \%14.33 oranında ASA şeklinde spermlere karşı immünite tespit edilmiştir. ASA'nın bu hayvanlarda infertilite nedenlerinden biri olabileceği düşünülmektedir. Saha şartlarında en az 3 kere tohumlanıp gebe kalmayan inekler kesime gönderilmeden immünolojik infertilite yönünden değerlendirilmeli, tedavi uygulanıp gebelik takip edilmelidir. Böylelikle basit bir kortikosteroid tedavisi ile bile bir inek kesimden kurtularak yavru elde edilebilir ve ülke genelinde büyük ekonomik kayıplar önlenebilir. Ayrıca ASA'nın sığır ve diğer çiftlik hayvanlarında doğurganlık üzerindeki etkileri üzerine insanlarda yapılanlara benzer şekilde daha ileri araştırmalara ihtiyaç olduğu düşünülmektedir.

\section{Kaynaklar}

Alexander NJ, Anderson DJ, 1989: Immunological factors in reproductive fitness. In "Reproduction in Mammals", Ed; Austin CR, and Short RV, Cambridge Universty Press, Cambridge.

Ahuja AK, Cheema RS, Kumar A, 2016: Status of naturally developing antisperm antibodies in serum of calves, heifers, cows and their effect on in vitro capacitation and acrosome reaction. J Bio Innov 5 (6), 874-889.

Bradley MP, Hinds LA, Bird PH, 1997: A bait-delivered immunocontraceptive vaccine for the european red fox by the year 2002? Reprod Fert Dev, 9, 111-116.

Doğan I, Gökçen H, 2001: Döl tutmayan inek ve düvelerde penetrasyon testinin kullanım olanakları. J Fac Vet Med, 20, 91-98.

Kim CA, Parrish JJ, Momont HW Lunn DP, 1999: Effects of experimentally generated bull antisperm antibodies 
on in vitro fertilization. Bıology of Reproduction, 60, 1285-1291.

Minbay A, Aydın N, Akay Ö, İzgür M, Diker S, 1994: İmmunoloji, Medisan Yayınevi, Ankara, Türkiye.

Naz RK, 1999: Vaccine for contraception targeting sperm. Immunol Rev, 171, 193-202.

Panchal MT, Dholakia PM, Derashri HJ, Kodagali SB, 1990: Investigation on immunoinfertility in repeat breeding buffaloes. Indian J Anim Sci, 60, 12111212.

Price RJ, Roberts TK, Gmm D, Boettcher B, 1984: Anticomplementary activity in human semen and its possible importance in reproduction. Amer J Reprod Immunol, 6, 92.

Rhoades RA, Bell DR, 2017: Klinik Tıbbın Temelleri, İstanbul Tıp Kitabevleri, İstanbul, Türkiye.

Risvanli A, Kaygusuzoglu E, 2004: Immunological infertility in domestic animals. J Turk Vet Med, 3-4, 52-55.

Risvanli A, Aydin M, Kaygusuzoglu E, Bulut $H$, Apaydin AM, Bolat $Y, 2005$ : The prevalence of antisperm antibodies in cattle in the eastern anatolian region of Turkey. Irish Vet J 49, 45-48.
Srivastava SK, Shinde S, Singh SK, Werma MR, Singh AK, Nandi S, Srivastava S, Goswami TK, Bhure SK, Kumar H, Ghosh SK, 2016: Antisperm antibodies in repeat-breeding cows: Frequency, detection and validation of threshold levels employing sperm immobilization, sperm agglutination and immunoperoxidase assay. Reproduction in Domestic Animals, 52, 195-202.

Waziri MA, Fayemi OE, 2000: Seroprevalence of sperm antibodies in goats. Veterinarski Archiv, 70, 95-102.

Wolff H, Schill WB, 1985: Antisperm antibodies in infertile and homosexual men: relationship to serological and clinical findings. Fertility and Sterility, 44, 673.

Zral Z, Bendova J, Diblikova I, Vecova D, Kummer V, Makova J, Vulnik Z, 2002: Antisperm antibodies in blood sera of bulls and correlations with age, breed and ejaculate quality. Acta Vet Brno 71, 303-308.

*Yazışma Adsresi: İshak GÖKÇEK

Mustafa Kemal Üniversitesi Veteriner Fakültesi Fizyoloji Anabilim Dalı, Hatay, Türkiye

e-mail: ishakgokcek@hotmail.com 